\title{
EKSTREMOFIL SEBAGAI PENGHASIL ENZIM YANG POTENSIAL UNTUK APLIKASI INDUSTRI PANGAN DAN NON PANGAN
}

\author{
Dewi Seswita Zilda*)
}

\begin{abstract}
ABSTRAK
Lingkungan ekstrem diketahui ternyata menunjang kehidupan bagi berbagai jenis mikroorganisme yang dikenal dengan sebutan ekstremofil. Mikroorganisme yang tumbuh dan berkembang di lingkungan yang ekstrem ini menghasilkan biokatalis dengan sifat-sifat yang dapat memenuhi standar proses industri. Untuk memenuhi permintaan yang semakin tinggi, eksplorasi yang semakin intensif terhadap biokatalis ini terus dilakukan. Beberapa mikroorganisme ekstremofilik telah diisolasi dan enzim yang dihasilkannya telah dikarakterisasi dan diaplikasikan dalam industri makanan, detergen, pengolahan kayu, dan proses-proses bioteknologi. Enzim-enzim ini mempunyai kestabilan yang tinggi terhadap $\mathrm{pH}$, suhu, salinitas, dan kondisi ekstrem lainnya.
\end{abstract}

KATA KUNCI: ekstremofil, enzim industri

\section{PENDAHULUAN}

Pada beberapa tahun terakhir, eksplorasi enzim (biokatalis) banyak dilakukan untuk keperluan sintesis berbagai bahan obat-obatan yang kompleks, bahan industri makanan, pakan, serta bahan-bahan kimia tertentu untuk berbagai keperluan. Kemajuan yang pesat dalam teknologi DNA rekombinan, metode high troughput cultivation, genomic, dan proteomic turut menghangatkan perkembangan baru akan biokatalis dan proses biokatalisis. Hal ini ditunjukkan dengan pemanfaatan enzim untuk industri yang meningkat dari US\$1 juta pada tahun 1995 (Godfrey \& West, 1996) menjadi US\$ 1,5 juta pada tahun 2000 (McCoy, 2000).

Dipacu oleh peningkatan kebutuhan industri terhadap biokatalis yang mampu memenuhi kondisi proses industri, maka berbagai usaha dilakukan secara intensif untuk menemukan enzim seperti ini. Bila dibandingkan dengan sintesis secara organik, biokatalis mempunyai banyak kelebihan, seperti kemampuannya untuk melakukan proses produksi yang lebih efisien, menghasilkan lebih sedikit reaksi samping, dan beban lingkungan yang lebih rendah (Rozell, 1999). Meskipun pada saat ini lebih dari 3.000 jenis enzim telah diidentifikasi dan kebanyakan telah digunakan dalam industri maupun dalam bidang bioteknologi, pada kenyataannya enzim yang ada masih tidak mencukupi untuk memenuhi semua permintaan. Penyebab utamanya adalah tidak sesuainya sifat-sifat enzim dengan kondisi reaksi industri (Van den Burg, 2003). Enzim-enzim tersebut kebanyakan dihasilkan dari mikroorganisme mesofilik, yang walaupun mempunyai banyak kelebihan, namun penggunaannya sangat terbatas karena kerentanan stabilitasnya terhadap $\mathrm{pH}$, suhu, salinitas, kekuatan ion, dan beberapa kondisi ekstrem lainnya. Perhatian kemudian tertuju pada mikroorganisme yang sanggup bertahan pada lingkungan ekstrem yang diduga kuat dapat menghasilkan enzim dengan sifat-sifat yang sama (Herbert, 1992; Madigan \& Marrs, 1997).

Ekstremofil adalah organisme yang mampu bertahan hidup pada kondisi ekstrem atau bahkan membutuhkan kondisi tersebut untuk beraktivitas dan berkembang biak sementara bagi makhluk lainnya kondisi tersebut justru mematikan. Beberapa faktor ekstrem itu adalah suhu, $\mathrm{pH}$, salinitas, tekanan, dan beberapa kondisi lainnya. Hasil penyesuaian terhadap lingkungan ini menyebabkan mikroorganisme ekstremofilik mempunyai sifat-sifat unik yang dibutuhkan dalam proses bioteknologi sehingga mempunyai daya jual yang sangat tinggi untuk industri. Kemampuan ekstremofil bertahan pada kondisi yang tidak standar dan lingkungan yang non-konvensional memunculkan asumsi bahwa sifat-sifat enzim yang dihasilkan juga mampu beraktivitas optimum pada kondisi tersebut.

Dalam tulisan ini akan dibahas mengenai mikroorganisme ekstremofilik dan lingkungannya, serta enzim potensial yang dihasilkan beserta aplikasinya dalam industri.

\section{LINGKUNGAN EKSTREM}

\section{Suhu}

Di alam, makhluk hidup menghuni lingkungan mulai dari suhu tinggi, yaitu hipertermofil dengan suhu pertumbuhan maksimum $>80^{\circ} \mathrm{C}$, sampai pada suhu

\footnotetext{
*) Peneliti pada Balai Besar Riset Pengolahan Produk dan Bioteknologi Kelautan dan Perikanan
} 


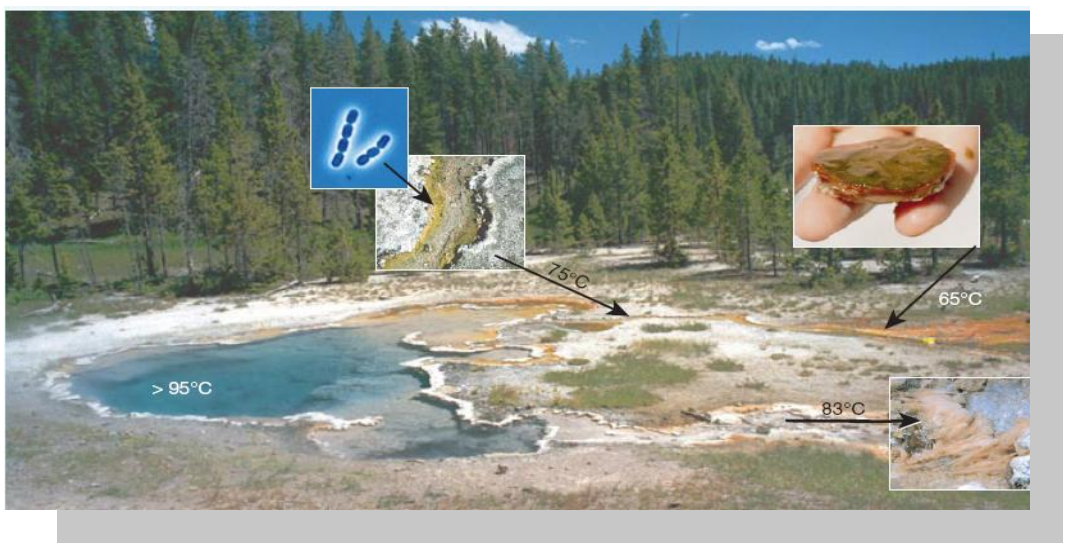

Gambar 1. Taman Nasional Yellowstones, USA, sumber dari beberapa jenis ekstremofil (Rothschild \& Mancinelli, 2001).

rendah, yaitu psikrofil dengan suhu pertumbuhan $<-15^{\circ} \mathrm{C}$. Masing-masing kelompok mempunyai batasbatas toleransi terhadap suhu untuk tumbuh dan beraktivitas.

Termofil adalah mikroorganisme yang mampu bertahan hidup, tumbuh, dan bahkan membutuhkan suhu yang tinggi untuk bisa beraktivitas, yaitu pada suhu $70-80^{\circ} \mathrm{C}$ (termofil) dan $85^{\circ} \mathrm{C}$ sampai lebih dari $100^{\circ} \mathrm{C}$ (hipertermofil). Contoh mikroorganisme yang termasuk ke dalam hipertermofil adalah Pyrolobus fumarii, yang dapat tumbuh pada suhu mencapai $113^{\circ} \mathrm{C}$ (Blochl et al., 1997). Enzim dari hipertermofil bahkan bisa stabil pada suhu yang lebih tinggi seperti enzim amilopullulanase yang mempunyai suhu optimum mencapai $142^{\circ} \mathrm{C}$ (Schuliger et al., 1993). Beberapa bakteri fototropik, yaitu bakteri yang membutuhkan cahaya untuk tumbuh dan beraktivitas seperti Cyanobacteria, eubacteria (Bacillus, Clostridium, Thiobacillus, Desulfotomacullum, Thermus, bakteri asam laktat, Actinomycetes,
Spirochetes), dan Archaea (Pyrococcus, Thermococcus, Thermoplasma, Sulfolobus, Methanogens), termasuk ke dalam kelompok ini (Rothschild \& Mancinelli, 2001).

Lingkungan yang dingin juga merupakan sumber kehidupan ekstremofil. Misalnya laut dalam dengan suhu antara $1-4^{\circ} \mathrm{C}$ yang menutupi lebih dari setengah permukaan bumi. Selain itu, daratan yang sangat luas dan selalu membeku di Artik dan Antartika secara mengejutkan mampu menunjang suatu kehidupan. Mikroorganisme yang tumbuh di lingkungan bersuhu rendah ini dikenal dengan sebutan psikrofil. Moraxella sp. (Tutino, 1999) dan Psyichrobacter (Rothschild \& Mancinelli, 2001) merupakan contoh dari mikroorganisme yang termasuk ke dalam golongan ini.

\section{Salinitas}

Lingkungan dengan kadar garam tinggi, seperti laut mati, danau dengan kadar garam tinggi, dan kolam

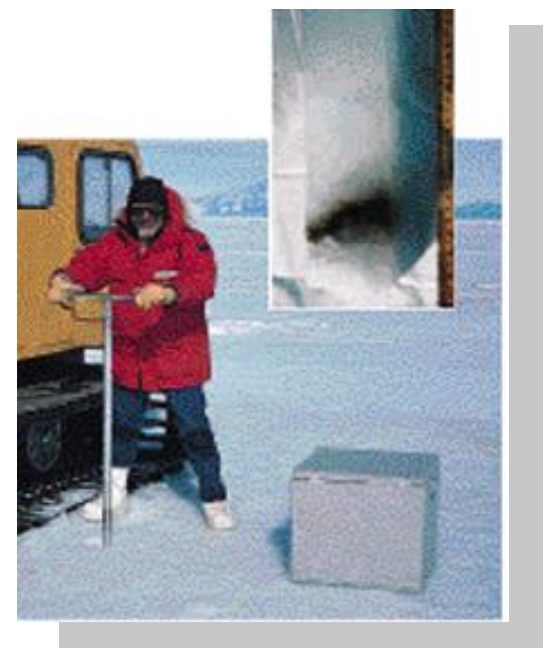

Gambar 2. Pengambilan sampel es di Antartika untuk isolasi psikrofil (Rothschild \& Mancinelli, 2001). 
pembuatan garam, merupakan habitat bagi ekstremofil yang lebih dikenal dengan sebutan halofil, yaitu mikroorganisme yang membutuhkan garam untuk pertumbuhannya. Nonhalofil yang dapat tumbuh dengan adanya garam disebut halotoleran. Halotoleran yang dapat tumbuh pada konsentrasi $15 \% \mathrm{NaCl}(2,5$ M) disebut dengan halotoleran ekstrem (Margesin \& Schimer, 2000). Kamekura (1998), membagi halofil ke dalam 3 kelompok yaitu aerobic halophilic Archaea (Halobacterium, Halococcus, Haloarcula), halophilic Methanogenic Archaea (Methanohalophilus, Methanohalobium), dan halophilic halobacteria (Actinoholispora halophila).

\section{$\mathrm{pH}$}

Proses biologi cenderung terjadi pada $\mathrm{pH}$ netral, seperti kebanyakan $\mathrm{pH}$ intraselular dan $\mathrm{pH}$ lingkungan yang juga berada pada kisaran ini. Pengecualian terdapat pada asidofil dan alkalifil (Gambar 4). Asidofil adalah mikroorganisme yang dapat atau membutuhkan kondisi lingkungan dengan $\mathrm{pH}$ di bawah 5 untuk tumbuh dan beraktivitas, sementara alkalifil membutuhkan $\mathrm{pH} 9$ atau lebih. Lingkungan asam bisa terjadi secara alamiah dari aktivitas geotermal seperti kawah hidrotermal yang menghasilkan gas sulfur. Aktivitas metabolik dari mikroorganisme terkadang juga menghasilkan suasana asam. Dari sumber inilah asidofil sering ditemukan. Lingkungan lainnya adalah sumber air panas dan lokasi penambangan timah. Contoh mikroorganisme yang termasuk ke dalam kelompok ini adalah beberapa spesies kapang (Acontium cylatium, Cephalosporium sp., dan Trichosporoncerebriae) yang tumbuh pada pH mendekati 0 (Schleper et al., 1995a) dan beberapa heterotrop aerob (Picrophilus oshimae dan Picrophilus torridus) dengan $\mathrm{pH}$ pertumbuhan 0,7 (Schleper et al., 1995b).

Alkalifil adalah organisme yang tumbuh optimal pada $\mathrm{pH}$ di atas 9 , umumnya antara $\mathrm{pH} 10-12$, tetapi tidak dapat tumbuh atau tumbuh dengan lambat pada $\mathrm{pH}$ netral sekitar 6,5. Berdasarkan fisiologinya, alkalifil terdiri atas 2 kelompok utama, yaitu alkalifil dan haloalkalifil. Haloalkalifil membutuhkan 2 kondisi ekstrem sekaligus untuk pertumbuhan, yaitu $\mathrm{pH}$ alkalin dan salinitas tinggi di atas 33\% (w/v). Alkalifil umumnya diisolasi dari lingkungan netral. Beberapa diantaranya juga diisolasi dari sampel tanah asam dan feses. Haloalkalifil biasanya ditemukan pada

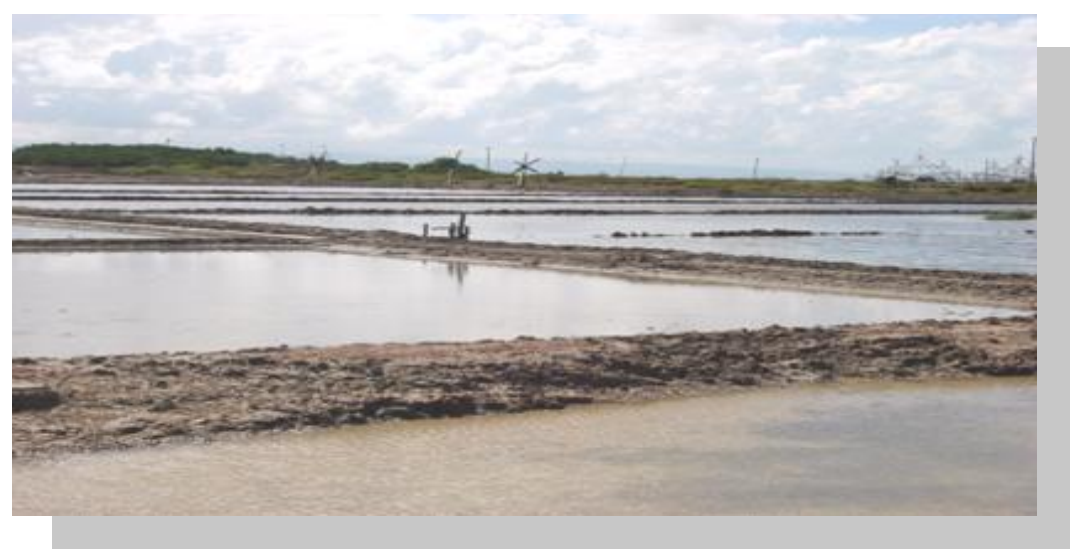

Gambar 3. Tempat isolasi halofil di kolam pembuatan garam Pamekasan, Madura.

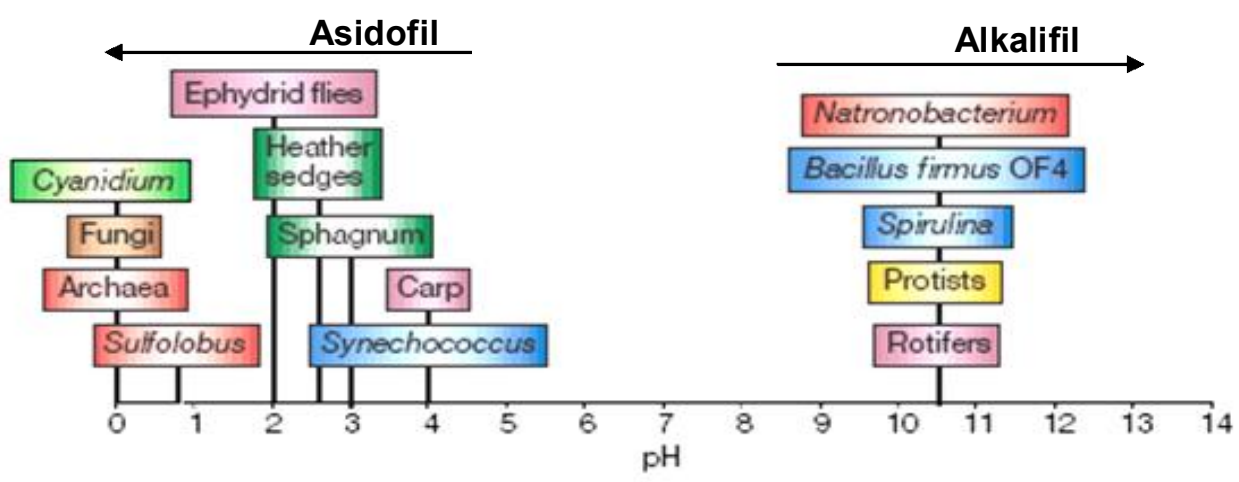

Gambar 4. Batas-batas pH kehidupan mikroorganisme (Rothschild \& Mancinelli, 2001). 
lingkungan ekstrem alkali yang bergaram seperti pada danau di Lembah Rift, Afrika Timur, dan danau-danau soda di Amerika Barat (Horikoshi, 1999). Beberapa mikroorganisme yang termasuk dalam kelompok alkalifil adalah Amphibacillus xylanus (Kodama \& Koyama, 1997), Halobacterium trapanicum (Xu et al., 1999), dan Methanosalsus zhilinaeae (Kevbrin et al., 1997).

\section{Lingkungan ekstrem lainnya}

Beberapa kondisi lingkungan lainnya seperti tekanan, kadar oksigen, radiasi, konsentrasi bahan kimia, lingkungan vakum, dan berbagai kondisi lain yang berada pada level abnormal, dikategorikan sebagai lingkungan ekstrem. Pada lingkungan seperti ini beberapa mikroorganisme juga sudah berhasil diisolasi.

\section{APLIKASI ENZIM EKSTREMOFIL PADA INDUSTRI PANGAN DAN NON PANGAN}

Enzim ekstremofilik atau yang lebih dikenal dengan sebutan ekstremozim dihasilkan dari ekstremofil. Ekstremozim mempunyai kestabilan yang tinggi dan kemampuan untuk bisa aktif pada kondisi yang sebelumnya diduga tidak mungkin terjadi pada material biologi. Karena sebagian besar ekstremofil mempunyai metabolic pathway yang baru, maka kemungkinan besar enzim yang dihasilkan juga mempunyai sifat-sifat baru yang aplikatif.

Di antara ekstremozim yang saat ini sudah diaplikasikan, enzim termostabil adalah ekstremozim

Tabel 1. Jenis-jenis ekstremofil dan lingkungannya yang paling banyak digunakan dalam industri. Pemakaian enzim termostabil pada proses industri yang menggunakan suhu tinggi sangat berguna dalam proses pencampuran, karena pada proses ini terjadi penurunan viskositas cairan sehingga bahan dengan konsentrasi tinggi tetap mempunyai kelarutan yang rendah. Perpindahan massa juga meningkat pada suhu tinggi seperti yang terjadi pada reaksi-reaksi kimia. Selain itu, pada produksi yang menggunakan suhu tinggi, resiko kontaminasi bisa dihindari atau bahkan dihilangkan sama sekali.

Aplikasi yang paling banyak dari enzim termostabil adalah liquefaction pati menggunakan amilase dari $B$. licheniformis and $B$. stearothermophilus. Protease juga merupakan produk andalan dari termofil yang banyak dipakai pada industri pengolahan makanan dan detergen. Beberapa industri terbaru dari enzim termostabil adalah produksi siklodekstrin menggunakan cyclodextrin glycosyl transferase (CGTase) dan bleaching bubur kayu menggunakan xilanase. Enzim lain yang menjadi perhatian adalah termolisin yang dihasilkan oleh Bacillus thermoproteolyticus (Endo, 1962). Termolisin adalah protease netral yang membutuhkan seng untuk aktivitasnya dan kalsium untuk kestabilannya terhadap panas. Enzim komersial dengan merek dagang SP-369 yang mempunyai sifat-sifat hampir sama dengan termolisin telah diaplikasikan untuk hidrolisis protein pada suhu tinggi, produksi aspartam, serta peptida lain. Selain itu, lipase termostabil non spesifik yang diisolasi dari Candida antarctica (suhu optimum $70^{\circ} \mathrm{C}$ ) diaplikasikan untuk sintesa ester (Heldt-Hansen et al., 1989), sintesa glikolipid (Bjorkling et al., 1989), dan untuk asidolisis (Bruce et al., 1991).

\begin{tabular}{|c|c|c|}
\hline Jenis e kstremofil & Lingkungan & Contoh mikroorganisme \\
\hline Termofil & $55-80^{\circ} \mathrm{C}$ & $\begin{array}{l}\text { Methanobacterium, Thermoplasma, } \\
\text { Thermus, beberapa Bacillus sp. }\end{array}$ \\
\hline Hipertermofil & $>80^{\circ} \mathrm{C}$ & $\begin{array}{l}\text { Aquifex, Archaeoglobus, Hydrogenobacter, } \\
\text { Methanothermus, Pyrococcus, Pyrodictium, } \\
\text { Pyrolobus, Sulfolobus, Themococcus, } \\
\text { Thermoproteus, Thermotoga }\end{array}$ \\
\hline Psikrofil & $<15^{\circ} \mathrm{C}$ & Alteromonas, Psychrobacter \\
\hline Halofil & $2-5 \mathrm{M} \mathrm{NaCl}$ & $\begin{array}{l}\text { Haloarcula, Halobacterium, Haloferax, } \\
\text { Halorubrum }\end{array}$ \\
\hline Asidofil & $\mathrm{pH}<4$ & $\begin{array}{l}\text { Acidianus, Desulfurolobus, Sulfolobus, } \\
\text { Thiobacillus }\end{array}$ \\
\hline Alkalifil & $\mathrm{pH}>9$ & $\begin{array}{l}\text { Natronobacterium, Natronococcus, } \\
\text { beberapa Bacillus sp. }\end{array}$ \\
\hline
\end{tabular}


Tabel 2. Contoh-contoh ekstremofil dan aplikasi enzim dalam industri

\begin{tabular}{llll}
\hline \multicolumn{1}{c}{ Proses industri } & Biomolekul & Ke untungan & Mikroorganisme \\
\hline $\begin{array}{l}\text { Hidrolisis pati menjadi soluble } \\
\text { dekstrin, maltodekstrin, sirup } \\
\text { jagung }\end{array}$ & $\alpha$-amilase & Stabilitas tinggi & $\begin{array}{l}\text { Bacillus } \\
\text { stearothermophilus }\end{array}$ \\
$\begin{array}{l}\text { Bleaching kertas } \\
\text { Xilanase }\end{array}$ & $\begin{array}{l}\text { Pengurangan jumlah } \\
\text { pemutih yang } \\
\text { diperlukan }\end{array}$ & Termofil \\
$\begin{array}{l}\text { Pengolahan makanan, } \\
\text { pembuatan kue, pembuatan } \\
\text { bir, detergen }\end{array}$ & Protease & $\begin{array}{l}\text { Stabil pada } \\
\text { temperatur tinggi }\end{array}$ & Termofil \\
$\begin{array}{l}\text { Reaksi PCR } \\
\text { Dematangan keju, perusahaan polimerase }\end{array}$ & $\begin{array}{l}\text { Tidak membutuhkan } \\
\text { penambahan enzim } \\
\text { pada setiap siklus }\end{array}$ & Termofil \\
$\begin{array}{l}\text { Protease netral } \\
\text { susu }\end{array}$ & $\begin{array}{l}\text { Aktif pada suhu } \\
\text { rendah }\end{array}$ & Psikrofil \\
$\begin{array}{l}\text { Pemecahan polimer pada } \\
\text { detergen }\end{array}$ & $\begin{array}{l}\text { Protease, } \\
\text { selulase, lipase }\end{array}$ & $\begin{array}{l}\text { Meningkatkan } \\
\text { kemampuan enzim }\end{array}$ & Psikrofil \\
Bioremediasi & $\begin{array}{l}\text { Mengurangi } \\
\text { limbah minyak }\end{array}$ & $\begin{array}{l}\text { Bekerja efisien pada } \\
\text { air dingin }\end{array}$ & Psikrofil \\
\hline
\end{tabular}

Beberapa enzim dari psikrofil dan rekombinannya juga telah diproduksi dan dikarakterisasi. Contohnya adalah alkohol dehidrogenase dari Moraxela sp. (Tsigos et al., 1998), $\alpha$-amilase dari Alteromonas haloplanctis (Feller et al., 1992), aspartat transkarboamilase dari isolat bakteri strain TAD (Sun, et al., 1998), $\mathrm{Ca}^{2+}-\mathrm{Zn}^{2+}$ protease dari Pseudomonas aeruginosa (Villeret et al., 1997), sitrat sintetase dari isolat bakteri strain DS2-3R (Gerike et al., 1997), $\beta$ laktamase dari Psychrobacter immobilis (Feller et al., 1997), malat dehidrogenase dari Aquaspirillium arcticum (Kim et al., 1999), subtilisin dari bakteri Antartika (Narinx et al., 1997), dan triose pospat isomerase dari Vibrio marinus (Alvarez et al., 1998).

Enzim psikrofil seperti protease, lipase, amilase, dan selulase yang digunakan sebagai bahan tambahan detergen akan menurunkan kebutuhan energi selama proses pencucian. Penggunaan suhu rendah pada proses pencucian juga akan mengurangi resiko kerusakan terhadap bahan-bahan pakaian. Dalam industri tekstil, selulase psikrofil dapat meningkatkan kelembutan produk, menurunkan suhu proses, dan jumlah enzim yang digunakan, sehingga pada akhirnya dapat menurunkan biaya produksi. Pada industri susu, enzim $\beta$-galaktosidase yang digunakan pada suhu rendah bisa menurunkan jumlah laktosa yang sering menimbulkan alergi pada kebanyakan konsumen. Pada industri jus, enzim pektinase yang dapat bekerja pada suhu rendah dapat membantu pada proses ekstraksi, menurunkan viskositas, dan menghasilkan produk akhir yang lebih bening.

Enzim pertama yang diisolasi dari alkalifil adalah protease. Enzim ini dihasilkan dari Bacillus sp., strain 221 yang diisolasi dari tanah (Horikoshi, 1971). Enzim dari alkalifil seperti protease, selulase, dan lipase merupakan enzim paling banyak diaplikasikan pada industri detergen, yaitu sekitar $30 \%$ dari jumlah produksi enzim dunia (Horikoshi, 1999). Enzim lain yang dihasilkan dari alkalifil adalah $\alpha$-amilase (Kim et al., 1995) untuk memproduksi glukosa, maltosa, dan maltotriosa, siklomaltodekstrin glukanotransferase (Nomoto et al., 1986) untuk produksi siklodekstrin, dan xilanase (Nakamura et al., 1993) untuk proses bleaching pada industri kayu, dan pektinase pada industri kertas.

\section{POTENSI EKSTREMOFIL ASAL INDONESIA}

Indonesia, dengan keanekaragaman hayatinya yang sangat tinggi, merupakan sumber yang potensial untuk isolasi ekstremofil. Beberapa ekstremofil yang sudah diisolasi telah dilaporkan mampu untuk 


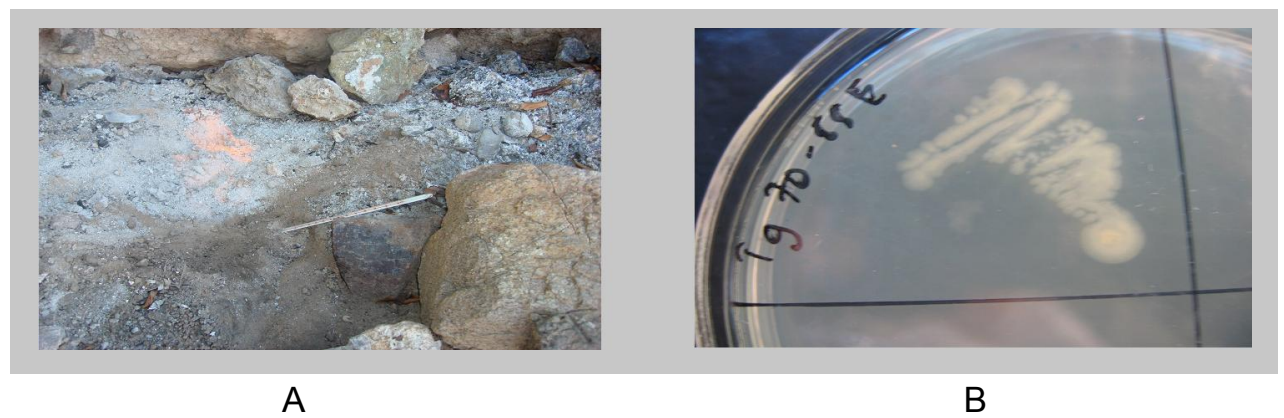

Gambar 5. Pasir panas pantai Pulau Togian (A) dan isolat bakteri termofil TG 70E pada media padat dengan $2,5 \%$ agar $(B)$.

menghasilkan enzim yang potensial (Chasanah, 2004; Mubarik, 2001).

Kelompok Peneliti Bioteknologi di Balai Besar Riset Pengolahan Produk dan Bioteknologi Kelautan dan Perikanan juga telah berhasil mengisolasi beberapa jenis ekstremofil, seperti termofil dan halofil. Tiga dari delapan isolat termofil yang diisolasi dari pasir panas Pulau Togian mampu tumbuh pada suhu $70^{\circ} \mathrm{C}$ setelah $12 \mathrm{jam}$ diinokulasikan pada media padat dengan 2,5\% agar (Gambar 5). Salah satu bakteri ini diidentifikasi sebagai Geobacillus stearothermophilus. Halofil yang diisolasi dari kolam pembuatan garam di Pamekasan, Madura diketahui dapat menghasilkan protease pada media dengan penambahan $\mathrm{NaCl}$ $12,5 \%$. Enzim ini masih mampu beraktivitas dengan keberadaan $\mathrm{NaCl} 7,5 \%$.

\section{PENUTUP}

Ekstremozim memiliki peluang ekonomi yang potensial dalam berbagai proses industri. Penggunaannya yang terus meningkat mendorong usaha eksplorasi yang lebih intensif terhadap enzim ini. Indonesia mempunyai prospek besar untuk penemuan ekstremofil. Hal ini disebabkan oleh kekayaan biodiversitasnya, di samping itu diketahui bahwa lingkungan ekstrem di Indonesia masih banyak yang belum terjamah. Hal ini tentu saja harus ditunjang dengan kegiatan riset untuk penemuan dan penguasaan metode baru dalam bidang kultivasi, bioproses, serta rekayasa genetika, sehingga mampu menghasilkan enzim ekstremofil untuk keperluan industri.

\section{UCAPAN TERIMA KASIH}

Ucapan terima kasih untuk Ariyanti, atas bantuan dan kesabarannya mencarikan literatur sehingga karya tulis ini bisa diselesaikan. Terima kasih juga untuk Gintung Patantis untuk suntingan awal.

\section{DAFTAR PUSTAKA}

Alvarez, M., Zeelen, J.Ph., Mainfroid, V., Rentier-Delrue, F., Martial, J.A., Wyns, L., Wierenga, R.K., and Maes, D. 1998. Triose phosphate isomerase (TIM) of the psychrophilic bacterium Vibrio marinus. J. Biol. Chem. 273: 2199-2206.

Bjorkling, F., Godtfredsen S.E., and Kirk, O. 1989. A highly simple selective enzyme-catalysed esterification of simple glucosides. J. Chem. Soc. Chem. Commun. p. 934-935.

Blöchl, E., Rachel, R., Burggraf, S., Hafenbradl, D., Jannasch, H.W., and Stetter, K.O. 1997. Pyrolobus fumarii, gen. and sp. nov., represents a novel group of archaea, extending the upper temperature limit for life to 113 7C. Extremophiles 1. p. 14-21.

Bruce L. Zamost, Henrik K., Nielsen, and Robert, L. Starnes. 1991. Thermostable enzymes for industrial applications. Review. J. of Industrial Microbiology. $8: 71-82$.

Chasanah, E. 2004. Characterization of Chitosanase of Bacillus licheniformis MB-2 from Manado Hot Spring Water. Dessertation, IPB, Bogor, Indonesia.

Endo, S. 1962. Studies of protease produced by thermophilic bacteria. Hakka Kogaku Zasshi 40: 346353.

Feller, G., Lonhienne, T., Deroanne, C., Libioulle, C., Van Beeumen, J., and Gerday, C. 1992. Purification, characterization and nucleotide sequence of the thermolabile a-amylase from the Antarctic psychrotroph A23. J. Biol. Chem. 267: 5217-5221.

Feller, G., Zekhnini, Z., Brasseur, J.L., and Gerday, C. 1997. The class C b-lactamase from the Antarctic psychrophile Psychrobacter immobilis A5. Eur. J. Biochem. 244: 186-191.

Gerike, U., Danson, M.J., Russell, N.J., and Hough, D.W. 1997. Sequencing and expression of the gene encoding a cold-active citrate synthase from an Antarctic bacterium strain DS2-3R. Eur. J. Biochem. 248: 49-57.

Godfrey, T. and West, S. 1996. Introduction to industrial enzymology. In Godfrey, T. and West, S. (eds.). Industrial Enzymology, edn 2. London: Macmillan Press:1-8.

Heldt-Hansen, H.P., Ishii, M., Paktar, S.A., Hansen, T.T., and Eigtved P. 1989. A new immobilized positional 
nonspecific lipase for fat modification and ester synthesis. In (Whitaker, J.R. and Sonnet, P.E., eds.) Biocatalysis in Agricultural Biotechnology, ACS Symposium Series 389. American Chemical Society, Washington, DC.

Herbert, R.A. 1992. A perspective on the biotechnological potential of extremophiles. Trends Biotechnol, 10:395-401.

Horikoshi, K. 1999. Production of alkaline enzymes by alkalophilic microorganisms.l. Alkaline protease produced by Bacillus no. 221. Agric. Biol. Chem. 35:1407-1414.

Horikoshi, K. 1971. Alkaliphiles: Some Applications of their product for biotechnology. Microbiology and Molecular Biology Reviews. 63: 735-749.

Kamekura, M. 1998. Diversity of extremely halophilic bacteria. Extremophiles. 2: 289-295.

Kevbrin, V.V., Lysenko, A.M., and Zhilina, T.N. 1997. Physiology of the alkaliphilic methanogen Z-7936, a new strain of Methanosalsus zhilinaeae isolated from Lake Magadi. Microbiology. 66: 261-266.

Kim, S.Y., Hwang, K.Y., Kim, S.H., Sung, H.C., Han, Y.S., and Cho, Y. 1999. Structural basis of cold adaptation. Sequence, biochemical properties and crystal structure of malate dehydrogenase from a psychrophile Aquaspirillium arcticum. J. Biol. Chem. 274: 11761-11767.

Kim, T.U., Gu, B.G., Jeong, J.Y., Byun, S.M., and Shin, Y.C. 1995. Purification and characterization of a maltotetraose-forming alkaline a-amylase from an alkalophilic Bacillus strain, GM8901. Appl. Environ. Microbiol. 61: 3105-3112.

Kodama, H. and Koyama, N. 1997. Unique characteristics of anaerobic alkalophiles belonging to Amphibacillus xylanus. Microbios. 89: 7-14.

Madigan, M.T. and Marrs, B.L. 1997. Extremophiles. Sci Am, April. p. 66-71.

Margesin, R. and Schinner, F. 2001. Potential of halotolerant and halophilic microorganisms for biotechnology. Extremophiles. 5: 73-83.

McCoy, M. 2000. Novozymes emerges. Chem Eng News. 19: 23-25.

Mubarik, N.R. 2001. Pemurnian dan Karakterisasi Protease Ekstraseluler dari Isolat Bakteri termofilik GP-04. Makalah seminar Program Pascasarjana IPB. Bogor, Indonesia.

Nakamura, S., Wakabayashi, K., Nakai, R., Aono, R., and Horikoshi, K. 1993. Production of alkaline xylanase by a newly isolated alkaliphilic Bacillus sp. strain $41 \mathrm{M}$ 1. World J. Microbiol. Biotechnol. 9: 221-224.
Narinx, E., Baise, E., and Gerday, C. 1997. Subtilisin from psychrophilic Antarctic bacteria: characterization and site-directed mutagenesis of residues possibly involved in the adaptation to cold. Protein Eng. 11: 1271-1279.

Nomoto, M., Chen, C.C., and Shen, D.C. 1986. Purification and characterization of cyclodextrin glucanotransferase from an alkalophilic bacterium of Taiwan. Agric. Biol. Chem. 50: 2701-2707.

Rothschild, L.J. and Mancinelli, R.L. 2001. Life in extreme environments. Nature. 409: 1092-1101.

Rozzell, J.D. 1999. Commercial scale biocatalysis: myths and realities. Bioorg Med Chem. 7: 2253-2261.

Schleper, C., Pühler, G., Kühlmorgen, B., and Zillig, W. 1995a. Life at extremely low $\mathrm{pH}$. Nature 375. 741742.

Schleper, C., Puehler, G., Holz, I., Gambacorta, A., Janekovic, D., Santarius, U., Klenk, H.P., and Zillig, W. 1995b. Picrophilus gen. nov., fam. nov.: a novel aerobic, heterotrophic, thermoacidophilic genus and family comprising archaea capable of growth around $\mathrm{pH}$ 0. J. Bacteriol. 177: 7050-7059.

Schuliger, J.W., Brown, S.H., Baross, J. A., and Kelly, R. M. 1993. Purification and characterization of a novel amylolytic enzyme from ES4, a marine hyperthermophilic archaeum. Mol. Mar. Biol. Biotech. 2: $76-87$.

Sun, K., Camardella, L., Di Prisco, G., and Hervé, G. 1998. Properties of aspartate transcarbamylase from TAD1 a psychrophilic bacterial strain. FEMS Microbiol. Lett. 164: 375-382.

Tsigos, I. 1998. Purification and characterization of an alcohol dehydrogenase from the Antarctic psychrophile Moraxella sp.TAE 123. Eur. J. Biochem. 254: 356-362.

Tutino, M.L. 1999. Aspartate aminotransferase from Moraxella TAC 125: an unusual psychrophilic enzyme. In Margesin, R. and Schinner, F. (eds.). Coldadapted Organisms. Springer. p. 305-316.

Van de Burg, B. 2003. Extremophiles as a source for novel enzymes. Current Opinion in Microbiology. 6: 213-218.

Villeret, V., Chessa, J.P., Gerday, C., and Van-Beeumen, J. 1997. Preliminary crystal structure determination of the alkaline protease from the Antarctic psychrophile Pseudomonas aeruginosa. Protein Sci. 6: 2462-2464.

Xu, Y., Zhou, P. J., and Tian, X. Y. 1999. Characterization of two novel haloalkaliphilic archaea Natronorubrum bangense gen. nov., sp. nov., and Natronorubrum tibetense gen. nov., sp. nov. Int. J. Syst. Bacteriol. 49: 261-266. 